\title{
PERBANDINGAN KEMAMPUAN PEMECAHAN MASALAH MATEMATIS MENGGUNAKAN MODEL PEMBELAJARAN SAVI DAN MODEL PEMBELAJARAN LANGSUNG SISWA KELAS VIII SMPN 2 KUALA TUNGKAL
}

\author{
Indri Jati Sugesti ${ }^{1}$, Risma Simamora ${ }^{2}$, Ayu Yarmayani ${ }^{3}$ \\ Program Studi Pendidikan Matematika, FKIP, Universitas Batanghari ${ }^{1,2,3}$ \\ Jl. Slamet Riyadi No.1 Broni Jambi \\ e-mail: -
}

\begin{abstract}
ABSTRAK
Penelitian ini adalah penelitian eksperimental. Populasi dalam penelitian ini adalah semua siswa kelas VIII SMPN 2 Kuala Tungkal Tahun Ajaran 2017/2018. Pengambilan sampel menggunakan simple random sampling sedangkan sampel penelitian diambil kelas VIII A dan VIII B. dimana dua kelas sampel diberi perlakuan berbeda. Dari hasil penelitian yang dilakukan nilai rata-rata untuk kelas eksperimen adalah 80,75 dengan standar deviasi 5,12 dan kelas kontrol rata-rata adalah 68,12 dengan standar deviasi 4,92 dan dari hasil uji hipotesis diperoleh thitung sebesar 10,1. dan tabel 1,67 pada tingkat nyata 0,05 . Dari perhitungan terlihat bahwa thitung lebih besar dari ttabel maka H1 diterima. Berdasarkan hasil akhir, dapat disimpulkan bahwa kemampuan pemecahan masalah siswa matematika yang menggunakan model pembelajaran SAVI (Somatic, Auditory, Visuallization, Intelektual) lebih baik daripada model pembelajaran langsung pada siswa kelas VIII SMPN 2 Kuala Tungkal.
\end{abstract}

\section{Kata kunci:}

Kemampuan Pemecahan Masalah Matematika, model pembelajaran SAVI (Somatik, Auditori, Visualisasi, Intelektual), Model Pembelajaran Langsung

\section{ABSTRACT}

This research is an experimental research. Population in this research is all students of class VIII SMPN 2 Kuala Tungkal Academic Year 2017/2018. Sampling using simple random sampling while the research samples are taken class VIII A and VIII B. where two classes of samples are given different treatment. From the results of research conducted the average value for the experimental class is 80,75 with standard deviation 5,12 and the average control class is 68,12 with standard deviation4,92 and from the results of hypothesis test obtained $t_{\text {count }}$ of 10,1 and table of 1,67 at the real level of 0,05. From the calculation it is seen that $t_{\text {count }}$ greather than $t_{\text {table }}$ then $H_{1}$ accepted. Based on the final result, it can be concluded that the problem solving ability of mathematics students using SAVI (Somatic, Auditory, Visuallization, Intellectually) learning model is better than the Direct learning model in students of grade VIII SMPN 2 Kuala Tungkal.

\section{Keyword:}

Mathematical Problem Solving Ability, SAVI (Somatic, Auditory, Visualization, Intellectualy) learning model, Direct Learning Model

\section{PENDAHULUAN}

Pendidikan adalah usaha sadar dan terencana untuk mewujudkan suasana belajar dan proses pembelajaran agar peserta didik secara aktif mengembangkan potensi dirinya untuk memiliki kekuatan spiritual keagamaan, pengendalian diri, kepribadian, kecerdasan, akhlak mulia, serta keterampilan yang diperlukan dirinya, masyarakat, bangsa, dan Negara. Pendidikan merupakan sejumlah pengalaman dari seseorang atau kelompok untuk dapat memahami sesuatu yang sebelumnya tidak mereka pahami (Ambarjaya, 2012). Selain itu pendidikan sebagai sarana untuk membentuk sumber daya manusia yang berkualitas dan bermutu. Untuk meningkatkan mutu 


\section{$\pi$ (Phi)}

pendidikan salah satunya melalui pembelajaran matematika.

Pembelajaran matematika adalah suatu proses belajar mengajar yang dibangun oleh guru untuk menggembangkan kreativitas berpikir siswa yang dapat meningkatkan kemampuan berpikir siswa, serta dapat meningkatkan kemampuan mengkontruksi pengetahuan baru sebagai upaya meningkatkan penguasaan yang baik terhadap materi matematika.

Matematika memiliki sifat kuantitatif, yakni dapat memberikan jawaban yang lebih rinci yang memungkinkan penyelesaian masalah secara lebih cepat dan cermat. Matematika dapat digunakan sebagai alat bantu untuk mengatasi permasalahan yang ditemui dalam kehidupan sehari-hari. Matematika merupakan metode berpikir secara logis. Sesuai dengan tujuan pendidikan yaitu salah satunya adalah untuk mewujudkan kemampuan individu, maka salah satu kemampuan yang ada pada pendidikan matematika adalah kemampuan pemecahan masalah matematis.

Kemampuan pemecahan masalah matematis merupakan salah satu kemampuan yang harus dimiliki siswa, karena pemecahan masalah memberikan manfaat yang besar kepada siswa dalam melihat relevansi antara matematika dengan mata pelajaran lain, serta dalam kehidupan nyata. Siswa dikatakan mampu memecahkan masalah matematika jika mereka dapat memahami, memilih strategi yang tepat, kemudian menerapkannya dalam penyelesaian masalah. Kemampuan pemecahan masalah matematis merupakan kemampuan dimana siswa berupaya mencari jalan keluar yang dilakukan dalam mencapai tujuan, juga memerlukan kesiapan, kreativitas, pengetahuan dan kemampuan serta aplikasinya dalam kehidupan sehari-hari.
Kemampuan pemecahan masalah matematis bukanlah kemampuan yang mudah untuk dicapai, Siswa akan berusaha memecahkan suatu masalah yang diberikan oleh guru jika menerima tantangan yang ada masalah tersebut. Sangat penting bagi guru untuk memformulasikan kalimat pada masalah yang akan disajikan kepada siswa dengan cara yang menarik, yang berkaitan dengan kehidupan nyata sehingga tidak terlalu abstrak. Dikenal dua macam masalah, yaitu soal cerita (textbook word problem) dan masalah proses (proses problem). Soal cerita merupakan pemecahan masalah yang diberikan setelah siswa mengetahui konsep atau teori dari materi yang dibelajarkan, sedangkan masalah proses diberikan di awal kegiatan, dimana siswa menemukan teori atau konsep materi berdasarkan masalah yang diberikan.

Pemecahan masalah matematika sering kita jumpai dalam bentuk soal cerita dalam kehidupan sehari-hari. Ini menjadikan matematika dapat dilihat secara realistis. Akan tetapi kenyataannya dari hasil observasi, siswa justru sulit memecahkan masalah matematika dalam bentuk soal cerita. Mereka sulit dalam mengidentifikasi masalah, memahami makna dari bahasa soal, mengambil keputusan dan sulit mengubah soal cerita kedalam model matematika. Mengingat pentingnya pemecahan masalah dalam proses pembelajaran matematika, maka setiap siswa dituntut untuk memiliki kemampuan dalam pemecahan masalah matematika. Namun kenyataan di lapangan menunjukkan masih banyak siswa yang mengalami kesulitan dalam menyelesaikan soal pemecahan masalah.

Mengingat begitu pentingnya kemampuan pemecahan masalah matematis siswa, maka diperlukan inovasi model pembelajaran matematika di dalam kelas. Salah satu upaya yang ingin diterapkan penulis untuk mengatasi permasalahan ini 
ialah dengan menerapkan model pembelajaran SAVI.

Menurut Lestari dan Yudhanegara (2015) SAVI merupakan model pembelajaran yang melibatkan gerakan fisik, berbicara, mendengarkan, melihat, mengamati, dan menggunakan kemampuan intelektual untuk berpikir, menggambarkan, menghubungkan, dan membuat kesimpulan. Melalui model pembelajaran SAVI siswa diajak untuk aktif bergerak dan berpikir dalam menemukan suatu konsep dengan bantuan alat peraga akan mengakibatkan pemahaman siswa terhadap konsep yang diajarkan lebih maksimal.

Pemecahan masalah matematis adalah proses yang menggunakan kekuatan dan manfaat matematika dalam menyelesaikan masalah yang juga merupakan metode penemuan solusi tahap-tahap pemecahan masalah, siswa yang terbiasa memcahkan masalah matematika akan meningkatkan potensi intelektualnya, dan rasa percaya diri siswa akan meningkat.

Menurut Killen (Susanto, 2013), "Pemecahan masalah sebagai strategi pembelajaran adalah suatu teknik dimana masalah digunakan secara langsung sebagai alat untuk membantu siswa memahami materi pelajaran yang sedang mereka pelajari”. Selain itu Fauzan (2011) mengemukakan kemampuan pemecahan masalah merupakan bagian dari kurikulum matematika yang sangat penting, proses pembelajaran maupun penyelesaian siswa dalam memperoleh pengalaman menggunakan pengetahuan serta keterampilan yang sudah dimiliki untuk diterapkan pada pemecahan masalah yang bersifat tidak rutin

Polya (Fauzan, 2011) mengatakan pemecahan masalah adalah salah satu aspek berpikir tingkat tinggi, sebagai proses menerima masalah dan berusaha menyelesaikan masalah tersebut. Kenyataan menunjukkan sebagian besar kehidupan kita adalah berhadapan dengan masalahmasalah. Kita perlu mencari penyelesaiaannya, bila kita gagal dengan suatu cara untuk menyelesaikan suatu masalah, maka kita harus mencoba menyelesaikannya dengan cara lain.

Pemecahan masalah memberikan manfaat yang besar kepada siswa dalam melihat relevansi siswa antara matematika dengan pelajaran lain, serta kehidupan nyata. Pemecahan masalah merupakan sarana sekaligus target dari pembelajaran matematika di sekolah. Sebagai sarana, pemecahan masalah memungkinkan siswa untuk mengkonstruksikan ide-ide matematis.

Mengajarkan kemampuan pemecahan masalah kepada siswa merupakan kegiatan dari seorang guru untuk membangkitkan kemampuan pemecahan masalah matematis pada siswa. Fauzan (2011) menguraikan ada tiga hal yang menjadi tanggung jawab guru saat menumbuhkan kemampuan pemecahan masalah matematis, yaitu: (1) membantu peserta didik mengembangkan kumpulan strategi pemecahana masalah; (2) membimbing peserta didik menguasai konsep matematika; (3) menyediakan kesempatan bagi peserta didik untuk menggunakan strategi tersebut dalam suatu variasi keadaan yang lebih luas.

Menurut Wena (2013) Pemecahan masalah sistematis (systematic approach to problem solving) adalah petunjuk untuk melakukan suatu tindakan yang berfungsi untuk membantu seseorang dalam menyelesaikan suatu permasalahan.

Kemampuan pemecahan masalah merupakan bagian dari kurikulum matematika yang sangat penting atau dapat dikatakan bahwa kemampuan memecahkan masalah merupakan hasil utama dari suatu proses pembelajaran. Secara umum pemecahan masalah yang sering digunakan adalah strategi yang dikemukakan oleh Polya (Susanto, 2013) dengan menyebutkan 


\section{$\pi$ (Phi)}

ada empat langkah dalam pembelajaran pemecahan masalah, yaitu: (1) Memahami masalah; (2) Merencanakan penyelesaian; (3) Melaksanakan rencana; (4) Memeriksa kembali proses dan hasil.

Berdasarkan langkah Polya tersebut dalam pemecahan masalah matematis ada beberapa indikator pemecahan masalah menurut Sumarmo (Fauzan, 2011), yaitu sebagai berikut: (1) Mengidentifikasi unsurunsur yang diketahui, yang ditanyakan dan kecukupan unsur yang diperlukan; (2) Merumuskan masalah matematika atau menyusun model matematika;

Menerapkan strategi untuk menyelesaikan berbagai masalah dalam atau luar matematika; (4) Menjelaskan atau menginterpretasikan hasil permasalahan menggunakan matematika secara bermakna. Guna mengevaluasi kemampuan pemecahan masalah matematis siswa.

Pembelajaran tidak otomatis meningkat dengan menyuruh orang berdiri dan bergerak kesana kemari. Akan tetapi, menggabungkan gerakan fisik dengan aktivitas intelektual dan penggunaan semua indra dapat berpengaruh besar pada pembelajaran. Model pembelajaran yang digunakan disini adalah model pembelajaran SAVI.

Menurut Shoimin (2014), Tahapan yang perlu ditempuh dalam model pembelajaran SAVI adalah persiapan, penyampaian, pelatihan, dan penampilan hasil. Tahap-tahap proses model pembelajaran SAVI adalah :

1. Tahap Persiapan (Kegiatan Pendahuluan). Pada tahap ini guru membangkitkan minat siswa, memberikan perasaan positif mengenai pengalaman belajar yang akan datang, dan menempatkan mereka dalam situasi optimal untuk belajar.

2. Tahap Penyampaian (Kegiatan Inti)

Pada tahap ini guru hendaknya membantu siswa menemukan materi belajar yang baru dengan cara melibatkan panca indra, dan cocok untuk semua gaya belajar.

3. Tahap Pelatihan (Kegiatan Inti)

Pada tahap ini guru hendaknya membantu siswa mengintegrasikan dan menyerap pengetahuan dan keterampilan baru dengan berbagai cara.

4. Tahap Penampilan Hasil (Tahap Penutup) Pada tahap ini hendaknya membantu siswa menerapkan dan memperluas pengetahuan atau keterampilan baru mereka pada pekerjaan sehingga hasil belajar akan melekat dan penampilan hasil akan terus meningkat.

Dengan membiasakan siswa menggunakan tahapan yang kreatif dalam memecahkan masalah, diharapkan dapat membantu siswa untuk mengatasi kesulitan dalam mempelajari matematika. Selain itu tahapan yang ada pada model pembelajaran SAVI untuk meningkatkan kemampuan intelektual siswa dalam pembelajaran matematika.

Model pembelajaran SAVI (Somatic, Auditory, Visualization, Intelectually) memiliki kelebihan dan kekurangan (Shoimin, 2014). Kelebihan model pembelajaran SAVI adalah: (1) Membangkitkan kecerdasan terpadu siswa secara penuh melalui penggabungan gerak fisik dengan aktivitas intelektual; (2) Memupuk kerja sama karena siswa yang lebih pandai diharapkan dapat membantu yang kurang pandai; (3) Memaksimalkan ketajaman konsentrasi siswa; (4) Melatih siswa untuk terbiasa berpikir dan mengemukakan pendapat dan berani menjelaskan jawabannya. Sedangkan kekurangan dari model pembelajaran SAVI adalah dalam penerapan model ini membutuhkan kelengkapan sarana dan prasarana pembelajaran yang menyeluruh dan disesuaikan dengan kebutuhannya sehingga memerlukan biaya pendidikan yang sangat besar.

Menurut Meier (Lestari dan Yudhanegara, 2015) SAVI merupakan 


\section{$\pi$ (Phi)}

model pembelajaran yang melibatkan gerakan fisik, berbicara, mendengarkan, melihat, mengamati, dan menggunakan kemampuan intelektual untuk berpikir, menggambarkan, menghubungkan, dan membuat kesimpulan, pelatihan, dan penampilan hasil. Tahap-tahap proses model pembelajaran SAVI adalah :

1. Tahap Persiapan (Kegiatan Pendahuluan) Pada tahap ini guru membangkitkan minat siswa, memberikan perasaan positif mengenai pengalaman belajar yang akan datang, dan menempatkan mereka dalam situasi optimal untuk belajar.

2. Tahap Penyampaian (Kegiatan Inti)

Pada tahap ini guru hendaknya membantu siswa menemukan materi belajar yang baru dengan cara melibatkan panca indra, dan cocok untuk semua gaya belajar.

3. Tahap Pelatihan (Kegiatan Inti)

Pada tahap ini guru hendaknya membantu siswa mengintegrasikan dan menyerap pengetahuan dan keterampilan baru dengan berbagai cara.

4. Tahap Penampilan Hasil (Tahap Penutup) Pada tahap ini hendaknya membantu siswa menerapkan dan memperluas pengetahuan atau keterampilan baru mereka pada pekerjaan sehingga hasil belajar akan melekat dan penampilan hasil akan terus meningkat.

Dengan membiasakan siswa menggunakan tahapan yang kreatif dalam memecahkan masalah, diharapkan dapat membantu siswa untuk mengatasi kesulitan dalam mempelajari matematika. Selain itu tahapan yang ada pada model pembelajaran SAVI untuk meningkatkan kemampuan intelektual siswa dalam pembelajaran matematika.

Model pembelajaran SAVI (Somatic, Auditory, Visualization, Intelectually) memiliki kelebihan dan kekurangan (Shoimin, 2014). Kelebihan model pembelajaran SAVI adalah: (1) Membangkitkan kecerdasan terpadu siswa secara penuh melalui penggabungan gerak fisik dengan aktivitas intelektual; (2) Memupuk kerja sama karena siswa yang lebih pandai diharapkan dapat membantu yang kurang pandai; (3) Memaksimalkan ketajaman konsentrasi siswa; (4) Melatih siswa untuk terbiasa berpikir dan mengemukakan pendapat dan berani menjelaskan jawabannya. Sedangkan kekurangan dari model pembelajaran SAVI adalah dalam penerapan model ini membutuhkan kelengkapan sarana dan prasarana pembelajaran yang menyeluruh dan disesuaikan dengan kebutuhannya sehingga memerlukan biaya pendidikan yang sangat besar.

Menurut Meier (Lestari dan Yudhanegara, 2015) SAVI merupakan model pembelajaran yang melibatkan gerakan fisik, berbicara, mendengarkan, melihat, mengamati, dan menggunakan kemampuan intelektual untuk berpikir, menggambarkan, menghubungkan, dan membuat kesimpulan.

Menurut Suprijono (2011), kelima fase pembelajaran langsung dapat dikembangkan sebagai berikut:

1. Directing. Guru menjelaskan tujuan pembelajaran kepada seluruh kelas dan memastikan bahwa semua peserta didik mengetahui apa yang harus dikerjakan dan menarik perhatian peserta didik pada poin-poin yang membutuhkan perhatian khusus.

2. Instruction. Guru memberikan informasi dan menstruksasikan dengan baik.

3. Demonstrating. Guru menunjukkan, mendeskripsikan, dan mebuat model dengan menggunakan sumber serta display visual yang tepat.

4. Eksplaining and illustrating. Guru memberikan penjelasan- penjelasan akurat dengan tingkat kecepatan yang pas dan merujuk pada metode sebelumnya.

5. Questioning and discussing. Guru bertanya memastikan seluruh peserta 


\section{$\pi$ (Phi)}

didik ikut ambil bagian. Guru mendengarkan dengan seksama jawaban peserta didik dan merespons secara kontruktif untuk mengembangkan belajar peserta didik. Guru menggunakan pertanyaan-pertanyaan terbuka dan tertutup. Guru memastikan bahwa peserta didik dengan semua kemampuan yang dimilikinya terlibat dan memberikan kontribusi didalam diskusi. Guru memberikan waktu kepada peserta didik untuk memikirkan jawabannya sebelum peserta didik menjawab.

6. Consolidating. Guru mmemaksimalkan kesempatan menguatkan dan mengembangkan apa yang sudah diajarkan melalui berbagai macam kegiatan dikelas. Guru dapat pula member tugas-tugas yang difokuskan dengan baik untuk dikerjakan dirumah.

7. Evaluating pupil's responses. Guru mengevaluasi presentasi hasil kerja peserta didik.

8. Summarizing. Guru merangkum apa yang telah diajarkan dan apa yang sudah dipelajari peserta didik selama dan menjelang akhir pelajaran.

Berdasarkan pendapat di atas maka dapat disimpulkan bahwa pembelajaran langsung adalah model pembelajaran yang ditransformasikan langsung oleh guru kepada siswa dimana guru lebih aktif dalam proses pembelajaran.

\section{METODE PENELITIAN}

Metode yang digunakan pada penelitian ini adalah metode eksperimen. Di dalam penelitian ini, yang menjadi populasi penelitian adalah siswa kelas VIII SMPN 2 Kuala Tungkal tahun ajaran 2017/2018. Teknik pengambilan sampel dalam penelitian ini adalah teknik simple random sampling (teknik acak). Pemilihan kelas eksperimen dan kelas kontrol digunakan secara undian, yang terpilih pertama sebagai kelas eksperimen yaitu kelas VIII A yang dibelajarkan dengan model pembelajaran SAVI (Somatic, Auditory, Visualization, Intelectually), dan yang terpilih kedua adalah kelas kontrol yaitu kelas VIII B merupakan kelas yang dibelajarkan menggunakan model pembelajaran langsung.

Dalam penelitian ini menggunakan penelitian berbentuk postest only control design. Sugiyono (2014) mengemukakan Ciri utama rancangan ini adalah sampel yang digunakan untuk eksperimen maupun sebagai kelompok kontrol diambil secara random dari populasi tertentu. Rancangan penelitian postest only control design seperti Tabel 1 berikut:

Tabel 1. Rancangan Penelitian

\begin{tabular}{ccc}
\hline Kelas & Treatment & Post-Test \\
\hline Eksperimen & $\mathrm{X}$ & $\mathrm{O}_{1}$ \\
Kontrol & - & $\mathrm{O}_{2}$ \\
\hline
\end{tabular}

\section{HASIL DAN PEMBAHASAN}

Hasil - hasil penelitian yang disajikan dalam penelitian ini ada dua bagian, yaitu hasil penelitian yang diperoleh melalui analisis statistik deskriptif dan analisis statistik inferensial. Analisis statistik deskriptif yang disajikan meliputi ukuran sampel, nilai rata-rata, nilai tertinggi, nilai terendah, simpangan baku, dan varians. Sedangkan analisis inferensial meliputi hasil uji-t.

Pada bagian ini dikemukakan karakteristik nilai dari masing- masing variabel penelitan. Adapun pengolahan datanya dilakukan secara manual dengan bantuan kalkulator.

Tabel 2. Karakteristik Nilai Hasil Post-Test Siswa

\begin{tabular}{ccc}
\hline Statistika & $\begin{array}{c}\text { Kelas } \\
\text { Eksperimen }\end{array}$ & $\begin{array}{c}\text { Kelas } \\
\text { kontrol }\end{array}$ \\
\cline { 2 - 3 } & Posttest & Posttest \\
\hline Ukuran Sampel & 32 & 32 \\
Rata-rata & 80,75 & 68,12 \\
Nilai Tertinggi & 90 & 75 \\
Nilai Terendah & 70 & 60 \\
Simpangan Baku & 5,12 & 4,92 \\
Varians & 26,25 & 24,24 \\
\hline
\end{tabular}


Berdasarkan Tabel 2 dapat dilihat bahwa jumlah siswa kelas eksperimen 32 orang dan jumlah siswa kelas kontrol 32 orang. Dari hasil posttest diperoleh nilai rata-rata kemampuan pemecahan masalah matematis pada kelas eksperimen adalah 80,75 dengan simpangan baku 5,12 dan nilai rata-rata kelas kontrol sebesar 68,12 dengan simpangan baku 4,92.

Tabel 3. Uji Normalitas Kelas Sampel

\begin{tabular}{|c|c|c|c|c|}
\hline Kelas Sampel & $\mathrm{N}$ & $\begin{array}{c}2 \\
\chi \text { Xhit }\end{array}$ & $\begin{array}{c}2 \\
\chi \mathrm{tab}\end{array}$ & Ket \\
\hline Ekspeimen & 32 & 4,35 & 7,81 & Normal \\
\hline Kontrol & 32 & 6,07 & 7,81 & Normal \\
\hline
\end{tabular}

bahwa jumlah siswa kelas eksperimen 32 orang dan jumlah siswa kelas kontrol 32 orang. Dari hasil posttest diperoleh nilai rata-rata kemampuan pemecahan masalah matematis pada kelas eksperimen adalah 80,75 dengan simpangan baku 5,12 dan nilai rata-rata kelas kontrol sebesar 68,12 dengan simpangan baku 4,92.

Tabel 4. Uji Homogenitas Varians Data Hasil Posttest Kelas Sampel

\begin{tabular}{lllllll}
\hline \multicolumn{2}{c}{ Varians } & \multirow{2}{c}{ Fhit } & Ftab & Keterangan \\
\hline Eksperimen Kontrol & & & & \\
\hline 26,25 & 24,24 & 0,05 & 1,08 & 1,84 & Homogen \\
\hline
\end{tabular}

Pada $\alpha=5 \%$ dengan dk pembilang= na $-1=32-1=31$ dan dk penyebut $=n b-$ $1=32-1=31$, maka didapat $\alpha($ na- 1$)$; (nb1) $=1,84$ karena $F_{\text {hitung }}<F_{\text {tabel }}$ yaitu $1,08<$ 1,84, maka dapat disimpulkan bahwa kedua kelompok mempunyai varians yang sama (homogen) maka $\mathrm{H}_{0}$ diterima.

Pengujian hipotesis ini dilakukan dengan uji t, karena data berdistribusi normal dan memiliki varians yang homogen. Hasil perhitungan uji hipotesis dapat dilihat pada Tabel 5 berikut ini:

Tabel 5. Perbandingan Rata-rata Hasil Tes Kemampuan Pemecahan Masalah Matematis Siswa

\begin{tabular}{cccccc}
\hline Kelas & $\mathrm{N}$ & Rata-rata & thit & $\mathrm{dk}$ & t tabel \\
\hline Eksperimen & 32 & 80,75 & & & \\
Kontrol & 32 & 68,12 & 10,1 & 62 & 1,67 \\
\hline
\end{tabular}

Berdasarkan hasil post-test bahwa kemampuan pemecahan masalah matematis siswa kelas Eksperimen nilai rata-ratanya adalah 80,75 dengan simpangan baku 5,12 sedangkan pada kelas Kontrol memiliki rata-rata 68,12 dengan simpangan baku 4,92 .

Berdasarkan perhitungan tersebut terdapat perbandingan antara kelas Eksperimen dan kelas kontrol. Setelah dilakukan perhitungan dengan menggunakan uji-t, didapat $t_{\text {hitung }}$ sebesar $=$ 10,1 dan $t_{\text {tabel }}$ sebesar 1,67. Karena $t_{\text {hitung }}$ lebih tinggi dibanding $\mathrm{t}_{\text {tabel }}$ sehingga $\mathrm{H}_{0}$ ditolak, dengan kata lain $\mathrm{H}_{1}$ diterima dengan tingkat kepercayaan $95 \%$. Hal ini berarti kemampuan pemecahan masalah matematis siswa kelas eksperimen lebih tinggi dibanding kelas kontrol.

Pada kelas ekperimen, setiap pembelajaran dimulai dengan salah satu siswa selalu diminta untuk membaca penjelasan singkat untuk materi yang akan dibelajarkan pada hari itu, kemudian siswa yang lainnya menyimak dan memperhatikan materi yang ada pada buku paket matematika mengenai materi yang dibacakan oleh salah satu temannya. Ini bertujuan untuk menyamakan kesiapan mereka dalam pembelajaran selanjutnya (Visual dan Auditory). Sedangkan untuk kelas kontrol diawal pembelajaran, hanya sebagian siswa yang terlihat membaca materi terlebih dahulu dan terlihat siap untuk belajar.

Dalam pembelajaran SAVI, setiap siswa dengan anggota kelompoknya saling berbagi pendapat dalam menyelesaikan masalah yang diberikan (Visual dan Auditory). Persaingan antar kelompok semakin membuat mereka lebih bersemangat dalam berdiskusi dan mengerjakan lembar kerja yang diberikan (Intellectualy). Mereka selalu siap ketika tiba-tiba ditanya dan diminta untuk menjelaskan penyelesaian dari setiap 


\section{$\pi$ (Phi)}

masalah yang diberikan (Auditory). Setiap kelompok yang berhasil menyelesaikan masalah yang diberikan dengan cepat selalu diminta salah satu perwakilannya untuk menjelaskan dan mengerjakan dipapan tulis (Somatic), sementara kelompok yang lain menyimak dan penjelasan temannya itu. Sedangkan untuk kelas kontrol, jangankan untuk menjelaskan, untuk mengerjakan dipapan tulis saja siswa tidak berani maju kedepan kelas, mungkin ini adalah akibat karena mereka tidak terbiasa terlatih dalam auditorinya.

Pada intinya, untuk kelas eksperimen setiap siswa benar-benar terlibat dalam pembelajarannya, mereka terlihat nyaman dengan model pembelajaran yang diterapkan. Berbeda dengan kelas kontrol, yang terlihat dalam pembelajaran hanya sebagian , hanya siswa-siswa yang mempunyai kemampuan lebih dalam bidang matematika. Adapun untuk sebagian siswa yang terlihat kemampuannya kurang mereka semakin terlihat bosan untuk belajar matematika. Hal tersebut mungkin disebabkan karena proses yang digunakan dalam pembelajaran terkesan membosankan.

Berdasarkan hasil penelitian, model pembelajaran SAVI (Somatic, Auditory, Visualization, Intelectually), pada pokok bahasan Operasi Aljabar yang diterapkan pada proses pembelajaran yang dilakukan oleh peneliti di SMPN 2 Kuala Tungkal memberikan dampak positif. Antara lain siswa lebih bisa menemukan sendiri konsep-konsep yang ada pada matematika kemudian memahami konsep-konsep tersebut, siswa lebih bertanggung jawab secara kelompok saat membuat dan menjawab pertanyaan, dan siswa lebih tekun dalam belajar sehingga siswa dapat menyelesaikan suatu permasalahan dengan baik, serta siswa lebih bertanggung jawab terhadap hasil diskusi kelompoknya. Selain itu siswa lebih terbiasa mengerjakan variasi soal yang berkaitan dengan materi Operasi Aljabar, sehingga mampu meningkatkan kemampuan pemecahan masalah matematis siswa dalam menyelesaikan soal

\section{SIMPULAN DAN SARAN}

Rata-rata kemampuan pemecahan masalah matematis siswa pada materi Operasi aljabar kelas eksperimen yang dibelajarkan dengan mengunakan model pembelajaran SAVI (Somatic, Auditory, Visualization, Intelectually) memperoleh nilai rata-rata 80,75 dengan simpangan baku 5,12 dan kemampuan pemecahan masalah matematis siswa pada materi Operasi aljabar kelas kontrol yang dibelajarkan dengan model pembelajaran langsung memperoleh nilai rata-rata 68,12 dengan simpangan baku 4,92. Hipotesisnya adalah Kriteria pengujian dari uji statistik dengan mengunakan uji-t, dimana diperoleh $t_{\text {hitung }}=10,1$ dan $t_{\text {tabel }}=1,67$. Sesuai dengan kriterian pengujian, jika $t_{\text {hitung }}>t_{\text {tabel }}$ maka $\mathrm{H}_{1}$ diterima, terdapat perbandingan kemampuan pemecahan masalah pada materi Operasi aljabar antar siswa yang mengunakan model pembelajaran SAVI (Somatic, Auditory, Visualization, Intelectually) dengan menggunakan model pembelajaran langsung. Ini berarti kemampuan pemecahan masalah siswa pada materi Operasi aljabar yang dibelajarkan dengan mengunakan model pembelajaran SAVI (Somatic, Auditory, Visualization, Intelectually) lebih baik dari pada pembelajaran menggunakan model pembelajaran langsung pada siswa kelas VIII SMPN 2 Kuala Tungkal.

1. Untuk meningkatkan hasil belajar siswa di sekolah, sebaiknya menggunakan model pembelajaran SAVI (Somatic, Auditory, Visualization, Intelectually) dalam proses pembelajaran khususnya pelajaran matematika pokok bahasan Operasi Aljabar.

2. Perlu adanya penelitian lebih lanjut 


\section{$\pi$ (Phi)}

sebagai pengembangan dari penelitian ini, terutama tentang hasil belajar matematika siswa.

\section{DAFTAR PUSTAKA}

Abdurahman, Mulyono. 2012. Anak Berkesulitan Belajar. Jakarta: Rineka Cipta.

Arifin, Zaenal. 2009. Evaluasi Pembelajaran. Bandung: PT. Remaja Rosdakarya.

Arihi, La Ode Safiun. 2012. Pendekatan, Metode, Strategi, dan Model-Model Pembelajaran. Yogyakarta: Multi Presindo.

Arikunto, Suharsimi. 2013. Dasar-dasar Evaluasi Pendidikan. Jakarta: Bumi Aksara.

. 2014. Prosedur Penelitian. Jakarta: Rineka Cipta.

Ambarjaya, Beni S, $2012 . \quad$ Psikologi Pendidikan dan pengajaran (Teori \& Praktik). Yogyakarta: CAPS.

Fauzan, Ahmad, 2011. Modul 1 Evaluasi Pembelajaran Matematika Pemecahan Masalah Matematika. Universitas Negeri Padang

Hamalik, Oemar. 2013. Kurikulum dan Pembelajaran. Jakarta: Bumi Aksara.

Hasan, Iqbal. 2006. Analisis Data Penelitian dengan Statistik. Jakarta: Sinar Grafika Offset.

Lestari, Karunia Eka, dan Yudhanegara, Mokhammad Ridwan. 2015. Penelitian Pendidikan Matematika. Bandung: PT Refika Aditama.

Shoimin, Aris. 2014. 68 Model Pembelajaran Inovatif Dalam Kurikulum 2013. Yogyakarta: Ar- Ruzz Media.

Slameto. 2010. Belajar dan Faktor-Faktor yang Mempengaruhinya. Jakarta: PT Rineka Cipta.

Sudjana. 2009. Metode Statistika. Bandung: Transito.

Sugiyono, 2014. Metode Penelitian Pendidikan. Bandung: Alfabeta.
2011. Metode Penelitian Kuantitatif dan Kualitatif dan $R$ \& D. Bandung: Alfabeta.

Suprijono, Agus, 2010. Cooperative Learning Teori dan Aplikasi PAIKEM. Yogyakarta : Pustaka Belajar.

Susanto, Ahmad. 2013. Teori Belajar \& Pembelajaran di Sekolah Dasar. Jakarta : Kencana.

Uno, Hamzah. 2008. Perencanaan Pembelajaran. Jakarta : Bumi Aksara.

Wena, Made. 2013. Strategi Pembelajaran Inovatif Kotemporer. Jakarta : Bumi Aksara. 